They possess a dorsal and ventral series of contractile gills, which make them differ from all other known fresh-water worms.

To summarize shortly a few of the other exhibits, we may mention Messrs. Pike and Harris's high tension apparatus; Mr. H. L. Callendar's platinum resistance pyrometers; the original specimen of Asteropecten Orion (Forbes), and a specimen of a slab of mountain limestone Bolland showing the passage of a foraminiferal ooze into crystalline calcite, by Prof. W. C. Williamson; Prof. Percy Frankland's crystals of active calcium glycerate (lævorotatory); and the two exhibits of turacin, one by Dr. C. A. MacMunn, showing the very remarkable spectrum it produces; the other by Prof. A. H. Church, who discovered this red pigment in the wing-feathers of certain plantain-eaters or Touracos. A very ingenious process of so-called colour photography was explained by Mr. F. Ives, of Philadelphia, who showed several pictures by means of a special optical lantern.

\section{THE SOUTH LONDON ENTOMOLOGICAL AND NATURAL HISTORY SOCIETY.}

THE annual Exhibition of this Society was held on the 5 th 1 and 6th inst., at "The Bridge House," London Bridge, S.E. The President, Mr. C. G. Barrett, F.E.S., in opening the Exhibition, gave a short account of the history of the Society from its formation by eleven South London entomologists in 1872 ; and he referred to the work done by members in rendering popular the study of biological science.

The exhibits were arranged in four rooms, and were very varied, including examples of nearly every order of the animal and vegetable kingdoms.

In the first room Mr. C. S. Cooper exhibited an almost perfect collection of British wild flowers and leaves; the Lambeth Field Club, Mollusca; Mr. J. T. Carrington, land shells from the Riviera, arranged so as to show variation; Mr. C. H. Collings a d Mr. D. W. Collings, British and Australian birds' eggs aud British birds; Mr. H. J. Turner and Mr. Rice, nests and egys of British birds, the latter having a double nest of the great titmouse (Parus major). The tables around this room were set apart for the exhibition of objects by aid of the microscope, and among so many it is difficult to make a selection; but the more important objects were those of Mr. T. D. Ersser, who showed the circulation of the blood in a gold carp, a most interesting subject; Mr. J. H. Stanley, spawn of perch; Mr. H. Groves, the circulation of sap in Nitella ; Mr. R. Macer, heads and eyes of various species of spider; Mr. West, freshwater Polyzoa; Mr. E. Hinton, preparations of the Hydroids, including the beautiful sea pen, killed with the tentacles fully extended; $\mathrm{Mr}$. W. B. Medland, the pulsation in the heart of a snail ; Mr. J. B. Medland, a section of the jaw of a mole, with the teeth in situ (polarized).

In the second room Mr. J. A. Cooper's birds' nests and eggs in natural clutches occupied one end, and were much admired: one of the principal features of this collection being that it is arranged to show the variation in different clutches of the eggs in one species. This was particularly noticeable in those of the red-backed shrike. Among the eggs there were white varieties of those of the chaffinch, lapwing, and great blackbacked gull ; variable series of the guillemot, razorbill, lapwing, and golden plover; also a series of nests containing eggs of the cuckoo, including nests of the wagtail, tree pipit, chaffinch, greenfinch, hedge sparrow, robin, flycatcher, yellow bunting.

In the class Insecta some of the more important exhibits were those of Mr. J. H. Leech, with sixteen drawers containing Palæarctic Lepidoptera. This collection attracted considerable attention. Mr. J. Jenner Weir showed exotic Rhopalocera, illustrating forms of mimicry, and fine examples of South African Ornithoptera. Mr. S. Edwards also contributed a large exhibit of exotic Rhopalocera. Adjoining these, was the Society's typical collection of Canadian Lepidoptera. Four drawers of European Neuroptera were shown by Mr. R. McLachlan. Mr. H. Moore exhibited a number of wasps' nests. Mr. T. R. Billup's exhibit comprised British Coleoptera, con= taining types of nearly all the known species; three drawers of Hemiptera-Heteroptera and one of Homoptera were beautifully arranged, and the adoption of a system of labelling giving the name of the species, the locality where taken, and date of capture, is much to be commended; seven drawers of Hymenoptera Aculeata, containing many rare species, also long series of Ichneumonidæ, many of the specimens being new to science, and others new to
Britain ; also two drawers of life-histories of Hymenopterous and Dipterous parasites, together with the larvæ and imagines of the Lepidopterous host. This last exhibit was one of the most interesting and instructive of the exhibition. Of British Lepidoptera there was a magnificent display, there being some forty exhibitors. Mr. R. South showed nearly the whole of his collection of Pyrales, Crambi, Pterophori, and Tortrices, a selection of Noctua, among which were extreme series of most of the polymorphic species in the group ; a drawer of Ly'cena icarus, showing the colour range of both sexes, one very blue female without black discoidal spots was especially interesting; a drawer of Geometræe showing that the colour and ornamentation of the female parent is transmitted to a large proportion of her offspring; Mr. C. G. Barrett, Pieris napi, one female of a light canary-yellow colour from Norfolk, others suffused with grey from South Wales, others with black spots and tips and dark nervures from the north of Ireland ; varieties of Anthocharis cardamines; long series of Odonestis potatoria, showing extreme variation, the colour in the males ranging from chocolate 10 a pale buff; also extensive series of varieties of Agrotis cursoria and A. tritici, from the east coast of England. Mr. Barrett also exhibited a drawer of varieties of Rhopalocera lent to him for the purpose of figuring in his book on the British Lepidoptera, by the Rev. Joseph Greene, the Rev. O. Pickard Cambridge, Dr. Wheeler, Mr. J. E. Robson, Mr. E. Sabine, and Mr. Sydney Webb. It is doubtful whether such a collection of varieties has been seen before, and those Lepido. pterists who pay special attention to the question of variation were much interested in the extraordinary varieties shown. $\mathrm{Mr}$. F. Merrifield, examples of Selenia illustraria, S. illunaria, S. lunaria, Eugonia alniaria, Vanessa urtice, Platypteryx falcataria, Arctia caia, Bombyx quercus and var. callune, bred by him in his experiments on the effect of temperature on the pupæ of certain species in causing variation. Labels were attached to each specimen showing the conditions to which the pupe had been subjected, and the results obtained from these. It appeared that a lower temperature produced examples which were darker and more intense in colour than those subjected to higher temperatures. A third drawer of $S$. illustraria and $S$. illunaria was shown, as illustrations of the effect of temperature applied for a very few days to pupæ at a sensitive stage, i.e. just before they began to show the colour, the forcing temperature was about $77^{\circ}$; the natural temperature about $40^{\circ}$ to $50^{\circ}$; a range of $15^{\circ}$ or less (at a point which it appeared was not yet actually ascertained between $57^{\circ}$ and $73^{\circ}$ ) was sufficient to produce the full temperature effects shown in the first two cases, but a range of much less than $13^{\circ}$, if at the right part of the thermometric scale, produced substantial difference of colsuring. Mr. W. Farren contributed examples from Cambridge including fine yellow specimens of Bryophila perla, and extensive series of $B$. muralis and $B$. impar of Warren ; these gave rise to considerable discussion among visitors as to whether impar was a true species or only a variety of muralis. Mr. R. S. Standen, a small box showing extreme varieties of Argynnida. Mr. Tugwell, a selection from his cabinet, including long series of Eugonia alniaria, Esp., melanic forms of Phigalia pedaria, Boarmia repandata, Tephrosia biunduilaria, \&c., and striking varieties of Abraxas grossulariata. Mr. C. G. Gregson also put in a magnificent series of varieties of this last-named species, some of the specimens being entirely suffused with the black markings, in others the yellow-coloured markings were wanting, and many were very pale forms, the black markings being absent; Mr. Gregson also showed Dianthacia conspersa, from various localities, to illustrate the local variation in that species-many of the forms were so extreme that he had given them varietal names. Mr. J. R. Wellman, his collection of Dianthœcia and Acidalia, also a drawer of Cidaria russata, bred and captured from various parts of Great Britain, a most interesting drawer as showing local variation. $\mathrm{Mr}$. F. W. Hawes, Rhopalocera, reared in 1890 and 1891 , chiefly from ova obtained by searching or from the captured female, thus enabling Mr. Hawes to ascertain the early life-histories of this group; among them were examples of Hesperia lineola, the species recently added to the British list by Mr. Hawes. Variation in Arctia caia was shown by Mr. Goldthwait, Mr. T. W. Hall, and Mr. A. Mera. Mr. C. H. Williams included in his series a gynandrous specimen of Argynnis paphia taken by him last summer in the New Forest, and much attention was paid to this beautiful specimen. Life-histories, the larvæ being mounted on

No. I I 76 , vOL. 46 ] 
the natural food-plant, were shown by Mr. J. A. Simes, Mr. A. Quail, and Mr. A. J. Croker, the latter gentleman's Phoroaesma smaragdaria being especially noticeable. Mr. R. Adkin exhibited a collection of British Sphinges and Bombyces, arranged with a view to showing local variation, such variation being well defined in some of the species of the genus Spilo. soma. Al*o a collection of Macro-Lepidoptera made at Rannoch, Perthshire, in I89I, illustrating an article on the local variation prevailing in that district recently contributed to the Entomologist. Mr. Tutt, extremely long and variable series of Noctuæ. Mr. Machin four drawers from his cabinet ; among the rarer species were Dicranura bicuspis and Drepana sicula.

In the third room there was a large exhibit of marine Mollusca, by Mr. Conishee. Mr. Step's exhibit of living Mollusca afforded a capital opportunity for comparing the mollusks as well as their shelIs. Between thirty and forty species were this shown, each in a separate glass, and ranged from the substantial Helix fomatia to the graceful Clausilia rugose among land snails; and from the large Anodons to the fragile Planorbis linentus among the aquatic species. Pond life was shown by Mr. Perks ; living newts, \&c., by Mr. R. Adkin, Jun. ; and living snakes, \&c., by Mr. Gee. A gigantic sponge was exhibited by Mr. Kedgley.

In a fourth room Mr. Reeves exhibited and explained an original set of diagrams, showing the correct positions of horses' legs while walking, trotting, and galloping, and to demonstrate their correctness the diagrams were transferred to a zoëtrope.

A large room was set apart for lectures, and during each evening crowded audiences listened to Mr. F. Enock, who lectured on "The Life-history of the British Trap-door Spider." The lecture was illustrated by Mr. Enock's original microphotographic slides, shown by means of the oxy-hydrogen lantern. Mr. E. Step's "Talk about Toadstools" was listened to attentively on each evening. The figures thrown on the screen were from Mr. Siep's own photographs and drawings. A third lecture was given by $\mathrm{Mr}$. George Day, illustrated by microphotographic slides, entitlcd "Domestic Friends and Foes."

\section{IMERINA, THE CENTRAL PROVINCE OF MADAGASCAR.}

$\mathrm{O}^{\mathrm{N}}$ Monday evening the Rev. James Sibree read a valuable paper on Imerina, the central province of Madagascar before the Royal Geographical Society. After an account of the work of recent explorers, of whom the French surveyors, MM. Catat and Maistre, and the English missionary, Mr. Baron, are the most important, Mr. Sibree came to the main subject of his paper, of which the following is an abstract.

M. Grandidier, who is now completing a splendid atlas of Madagascar, published a map of Imèrina on the scale of $1: 200,000$ in 1880 , and in $188_{3}$ an orographical map coloured according to the contour lines. The road from the port of Tamatave to Antananarivo, the Hova capital, in the centre of the Imèrina province remains a mere footpath, impassable either to wheeled vehicles or to beasts of burden ; and now, as 300 years ago, porters are the only means of transport.

Imèrina ("the elevated ") is bounded on the east by the steep ridge of forest-girdled mountain sloping to the Indian Ocean. The other boundaries are indistinct, and the total area of the province may be estimated at 7000 square miles. The general level of the province is from 4000 to 4500 feet above the sea. It is a mountainous region, abounding in peaks, which rise high above the breezy plateau, and marked also by many valleys. The most prominent summits are Angàvokely to the east, Ambòhimiangàra in the extreme west, Ihàranandriàna to the south, Milangàna, Ambóhimanòa, and Andringitra more central, and Ambòhipaniry and Vòhilèna to the north. The southwest of the province is dominated by the central mass of Ankàratra, a denuded volcano of great size, its peaks forming the culminating points of the island, and reaching nearly 9000 feet above the sea. The mountain-peaks are usually granite or gneiss, sometimes occurring in great rounded bosses, sometimes in fantastically carved pinnacles resembling from a distance Titanic forts, castles, and cathedrals. Decomposed granite covers a great part of the country with thick deposits of clay, sometimes white but more often tinted deep red by ferric oxide. Iron is abundant, gold has recently been discovered, graphite, galena, copper, and other useful minerals are also found in Imèrina.
The watershed of the island lies much nearer the east coast than the west, and the two chief rivers rising in the extreme east traverse the breadth of the province on their way to the Mozambique Channel. The Ikopa, fed by the Sisaony, the Andromba, the Màmba, and other streams, flows north-westward through the fertile plain of Bètsimilatatra, and farther north is joined by the Bètsibòka, under which name the united stream runs on to the sea at the Bay of Bembatoka. Lake Itàsy is the only large body of water in Imèrina, and probably owes its origin to volcanic subsidence.

On account of its altitude Imèrina has a pleasant temperate climate, although lying within the tropics. The south-east tradewinds, blowing fresh and moist over the forest belt and the wooded plains of the east, make the atmosphere peculiarly bracing in the cooler season. The annual rainfall at Antananarivo is about 53 inches. Through the clear pure air distant landscapes stand out with remarkable sharpness of outline. Towards sunset Imerina is seen in its most attractive aspect the hills, range beyond range, assume the richest shades of purple, the sky flames with crimson and gold, and the long clay walls of the native compounds glow like streaks of vermilion.

The general aspect of the province is bare, except for patches of primæval forest in the northern districts. Moor-like hills, which would look utterly dreary but for the marvellous atmospheric effects, predominate. Near Antananarivo the dried-up bed of an ancient lake, known as Bètsimitàtatra, forms a great plain, covered with rice-fields, which support a dense population. The steep sides of the river valleys are terraced, like great green staircases, with rice-plots, where the grain is sown broadcast, and whence the young plants are transplanted in the larger fields along the river-plains and in the meadows left by dried-up lakes.

The political subdivisions of Imèrina are mainly tribal, and are used for purposes of taxation, and for the apportionment of military levies and forced labour. No census has been taken, but an estimate based on the number of villages and houses justifies the estimate of the population at about I, 100,000. Except Antaananarivo, there are only small villages in the province, but these are clustered very closely together, especially to the north and north-west of the capital. Several of these were formerly tribal capitals, and Ambohimànga still retains nominal equality with Antananarivo in royal speeches. The old villages were always built on hills for purposes of defence, and surrounded by double or treble lines of fosses and embankments dug out of the hard red clay. A narrow bridge of the red clay leads to the gateway, which is formed of blocks of rock, either a circular slab ro or I 2 feet in diameter, which was rolled between upright gate-posts so as to block the way, or massive upright monoliths bearing strong wooden gates, In recent times the Hovas have largely deserted these fortresses, and built themselves villages close to the rice-fields. Graves of the aboriginal Vazimba are scattered over the province, but local feeling prevents any examination of these from being made.

\section{SOCIETIES AND ACADEMIES}

\section{PARIS.}

Academy of Sciences, May 2.-M. d'Abbadie in the chair. - The movements of minute organisms analyzed by means of chronophotography, by M. Marey. Using an arrangement described in the R'evue Générale de's Sciences in November last, and in NATURE, vol, xlv, p. 228, M. Marey has obtained photographs of the movements of blood corpuscles in the capillaries, and has analyzed the movements of zoosphores in the cells of a Cladophora. Enlargements from these negatives have been presented to the Academy. By taking a series of pictures at intervals of about one-tenth of a second, and projecting them upon a screen at about the same rate, the effect of the real motions of the object can be reproduced. The arrangement for doing this will be described in a future communication.-Observations of Swift's, Denning's, and Winnecke's comets, made at Algiers Observatory with the coudé equatorial, by MM. Rambaud and Sy. Observations of position are given.-On the approximation of functions of very large numbers, by M. Maurice Hamy. - On the tautochronism in a material system, by M. Paul Appell.-On the laws of electrolysis, by M. A. Chassy. When a substance having the formula $\mathrm{M}_{p} \mathrm{R}_{q}$ is electrolyzed, $M$ designating an electro-positive and $R$ an electro-negative radicle, one equivalent of the radicle $\mathrm{R}$, and $\frac{p}{q}$ equivalents of the radicle $\mathrm{M}$ NO. I I 76, VOL. 46] 